\title{
Pornography and Debasement of Womanhood in African Films: The Examples of Selected Nollywood and Ghallywood Videos
}

\author{
*Charles A. OGAZIE \\ **Ibitayo O. ODETADE
}

\begin{abstract}
No doubt, film has become a potent agent for social change in societies through its continued transition of historical, sociopolitical, religious and educational lessons channeled through its audio visual properties. In African societies for instance, film has captured the realities of existence thereby making its audience conscious of themselves and proffering a leeway out of so many misconstrued philosophies of life. But due to the unsatisfying and the rising audienceôs taste or superfluous directorial interpretations, African film makers principally those of Nollywood and Ghallywood have continued to trample on some hallowed African cultural heritage thereby promoting ñanti-Africanò norms and behaviours such as pornography, indecent dressing, vulgarity and uncultured sexual behaviours that are found in some Western films. Using the tenets of media content analysis of selected Nollywood/Ghallywood films, this paper believes that African films particularly those of Nollywood and Ghallywood should not be a means of promoting violence, ñgangsterismò, promiscuity, and sexual immorality. Instead, it should be seen asa viable tool for satirizing evil and promoting good in the society. The paper concludes that African filmmakers should strictly respect African culture and use film as a weapon for social change while entertaining their audience. It advocates also that film should not be used as a tool to showcase shame by debasing female gender in the name of meeting the demands of realism, making quick money
\end{abstract}

*Charles A. OGAZIE of the Adeyemi College of Education, Ondo, Nigeria

Email: charlesogazie@yahoo.com

**Ibitayo O. ODETADE of the Obafemi Awolowo University, Ile-Ife, Nigeria

Email: odetadeibitayo@gmail 
or gaining cheap popularity by portraying African women as ñprofessional sex objectsòin an attempt to please their audience.

Keywords: Pornography, Sex object, Debasement, African film, Womanhood, Sexual behaviours

\section{Introduction}

It has become seemingly impossible for anyone to separate man from arts in any given society. This is because every work of art is made by man and by implication, no other being produces art. Certainly, the arrangement of forms or materials in nature may have the same appeal to manôs senses as art does, but such arrangements are not usually organized as art. The reason for this is not farfetched. Among all other features accrued to art, art is known to involve a conscious or deliberate arrangement; it is composite, eclectic and communal in nature. Art is also known to be perceived by the senses. With the aforementioned, art is placed on the same pedestrian as being a highly creative rearrangement of nature which involves conscious efforts to bring to limelight.

Art is presented in multifaceted dimensions; it can be verbal, literary and through performance. Likewise the expression of art can also be in plastic, visual or in media format. Suffice it to say that paintings, sculptures, songs, dance, film/cinema for example, is unique products of art and it (art) has specific functions to play in the society. Film is an art that is considered to be ñnspired, imaginative, expressive, formally significant creativeòe it possesses the rare attribute of being ñdetective technically, morally and sociallyò (Adeleke, 2003). Invariably, it means that film is not just a piece of art but it is a tool of social reform as it expresses the feelings of humans by retelling the past, showcasing the present and foretelling the future.

Arguably, it can be said that film generally has become a microscopic lens in the hands of the artists with which they see and capture the minutest social issues and suggest ways out of the identified dilemma. From the foregoing, it is clear that film has 
acquired great popularity with the masses as it has become a powerful tool and an effective means of communicating important message(s) to all categories of audience in a language that is appreciated and understood. As a result of its audio-visual properties, film is said to have acquired great mass appeal. Thus, professional film makers make use of its rare properties to channel ñhallowedò multifaceted lessons. This feature makes film to stand out as a powerful platform for public awareness and co-operation in a task for nation-building. Since film is expected to perform all the aforementioned obligations to its audience, African film makers should make use of this medium to transmit change. With filmôs language (audio and visual), laudable religious, political, socio-cultural and moral messages are channeled through it while audiences are being entertained at the same time.

Gone are days when the media audiences are said to be neither hapless nor passive to communication content (Trenholm 1995; Bowman and Willis, 2003; Folarin, 2005; Bruun, 2007) but with the advent of recent studies, media audiences are beginning to be aware of the impact of the media on their everyday lives. And since inculcation of educational lessons is part of the major reasons why people participate in communication such as film, it is no use for ñnonprofessionalsò who are caught up in the ñwebò of making ñcheap fameò to debase African valued cultures in the name of producing films. To these few, film making has become a ñicensedò and innovative avenue to unleash their long conceived ñanti-Africanò behaviours such as nudity, vulgarity and uncultured sexual acts. And through their actions African values and culture are seen as barbaric in the minds of the innocent audience especially children and young adults, who may be incapable of separating good from bad. With their actions, these ñquasiprofessionalò film makers ñé embarrass their viewers with debased culture by creating characters that constantly rain abusive words and curses on whoever comes their waysò (Adeleke, 2003). This kind of behaviour is definitely ñan abuse of artò. Suffice it to say that the problem of assessing the social role and worth of art such as film/movie in society derives from what art itself is. 
Thomas Mann in Bamidele (2003) notes that: ñso many of us conceive of art (film) as a dreamerô idling fancy; it is for fun and game and more delusions and at best useless and meaningless without any validity to the moral or socialò. Contrary to this claim in literary parlance, film has so much to offer the society. It will only take the African film-makers, particularly those of Nollywood and Ghallywood to ñdeculturiseò film by discontinuing using film to ñexperimentò and ñshowcase popular behaviourò as dictated by audience to the detriment of African culture. Using the exact words of Opubor (1979),

If Black and African people are to intervene successfully in the protection of accurate images of their heritage (culture) in the media of the world, they must use the technology of the media in a way that is compatible with their ethos.

With the above, therefore, this paper tends to examine two Nollywood and two Ghallywood films respectively. It also examines how the selected film makers have debased womanhood and a few other African hallowed values for selfish purposes in spite of Opuborôs warnings.

\section{Brief History and Ideology of Ghanaian/Nigerian Films Industries}

The emergence of popular film/video industries in Ghana and Nigeria represents the most important and exciting development in African cultural production in recent history. Since its inception, African filmmaking has been a ñparadoxical activityò (Barlet, 2000: 238). Born out of the historical struggle of decolonization and having an obligation to represent ñAfrica from an African perspectiveò (Armes 2006), African film makers have continued to generate large audience on the continent.

In spite of the aforementioned achievements, film industry in Africa has become locked in a relationship of dependency with funding sources and distribution networks located around the 
world. As Sama, (1996) puts it African films remain ñforeigners in their own countriesò. Consequently, most African films are found in Europe and North America on film festival screens, on the internet and in university libraries than projected in cinemas or broadcast on television in Africa. This act is best described as ñgoing to see oneself in another manôs museumò. In another instance, most established cinema houses are found closed down for witnessing constant low patronage and not having enough films to show to the few audience members who visit the cinema houses. As a result, this has turned the few surviving cinema houses to religious worship centers and venues for social events giving way to people to stay more at home instead of going to the cinema to watch films made with celluloid.

Although the film medium has failed to take root in Africa due to several reasons, video has flourished. An inexpensive, widely available, and easy to use technology for the production, duplication, and distribution of movies and other media content, video, has radically transformed the African cultural landscape. In its most consequential manifestation, video has allowed video makers in Ghana and Nigeria, individuals who in most cases are detached from official cultural institutions and working outside the purview of the state, to create a tremendously popular, commercial cinema for audiences in Africa and abroad: feature ñfilmsò made on video. Freedom from the requirements of cultural and economic capital imposed by the film medium, ordinary Ghanaians and Nigerians started making and exhibiting their own productions in the late 1980s.

In Ghana for instance, the tremendous success of William AkuffoôZZinabu(1987), a full-length feature shot with a VHS home video camera, sparked what those working in the Ghanaian video industry call ñthe video boom. ò Local audiences, who had been watching scratched and faded foreign films for years, responded to Akuffoôs video movie with enormous enthusiasm. They crowded into the Globe Theatre in Accra for weeks to watch the video on the large screen. In a few years, film projectors in all of the major film theaters were replaced with video projection systems and hundreds of privately owned video centers, of various sizes and 
structural integrity, sprung up throughout the country to meet the growing demand for video viewing. Within ten years of the first local video production in 1987, as many as four videos in English were being released in Ghana each month, and over twenty years later, in 2009, Ghanaian movies appeared at the rate of approximately six per week, one in English and five in Akan, a Ghanaian language spoken across the country (Garritano, 2014).

Although, Ghanaian film industry which later became Ghallywood had it rosy in the beginning with the collection of nationalists and film professionals who took turns to build the foundation of film in Ghana before and after independence. But the influx of mainly amateur, from the late 1980 s to date, whose motive was profit rather than using the medium as a tool for national, social and cultural emancipation, further complicated the concept of film for development within the Ghanaian context.

In the case of Nigeria for instance, what is today christened as Nollywood started from the pioneer effort of Yoruba film makers. Although we have some scholars who recognize Living in Bondage produced in 1992 by Kenneth Nnebue as the first video film in Nigeria. Adeoti (2014) asserts that AladeAromire had earlier produced a video film in 1986 titled Ekun and as such Kenneth Nnebue cannot be said to be the first video film produced in Nigeria. What can be deduced from the argument above is to assert the pioneer effort of Yoruba film makers.

The Yoruba travelling theatre remains the nucleus of the development of cinematic culture in Nigeria. Practitioners of this theatrical practice move from one village to another, from one town to another. Having established the culture of touring performances, Hubert Ogunde made a landmark by resigning his appointment as a policeman and later established himself as a full fledge theatre practitioner. Along this period, there were other theatre practitioners that joined the terrain of travelling theatre. They include JimohAliu, OyinAdejobi, IsolaOgunsola andDuroLadipo (Ogunbiyi 1981, Adedeji and Hyginus, 1998). With the introduction of television station in Western Nigeria, the WNTV, the theatre practitioners of this era grabbed the opportunity of this new medium. The television medium began to deplete the theatre show of its patronage. Having a better understanding of this 
impending danger, the best practitioners of this era took solace in the much more glamorous audio-visual medium.

In some academic quarters, the introduction of video films was traced to the period of the oil boom. During this period, the price of oil radically increased in the stock market. This led to an increase in the revenue which was generated by Nigerian oil. The salaries of workers were reviewed upwards by commended committees. The increase was termed the ñUdoji Awardò. The working class was given fat wages and allowances, because of the excess disposable income and workers started acquiring properties. A lot acquired electrical and electronics goods such as radio sets, refrigerators, televisions. Many made extra effort to purchase video sets, because it was a new product then, but the cost was a bit high and only few people could afford it. As time went on, there was an increase in types and makers. This caused a reduction in the cost and brought it within the reach of the working class. Ownership of a video set is a sign of ñarrivalò among the young and the educated and nearly every home in the cities sought to own one (Okome and Haynes.1995; Ekwuazi 1991; Balogun, 1987 and Ogazie, 2009). While in another quarter it is believed that the early theatre practitioners who went into film encountered economic challenges in the production of motion picture films mainly because of the introduction of governmentôs policy on Structural Adjustment Programme (SAP). This problem made them shift their attention from producing celluloid films to video film production which has less financial burden than the former, because they could not stop doing what they know how to do best. As a result, an alternative was found in home video production and since then it has become a household name in the Nigerian film industry. Not minding which origin is true, one important thing is the fact that home video in Nigeria could be described as a child of circumstance which was birthed as a result of Nigerian economic situation. At a glance, it can be said that to understand African cinema is to interrogate issues of ideology, narrative, aesthetics, the economics of ownership and the role or social value of the cinematic product. 


\section{Concept of womanhood debasement in Africa}

Images of women occupy a central place in Nollywood and Ghallywood home videos and its scholarship. This is not because this discourse has remained an area that public analysts, commentators, feminist activists and academics have examined, but more because the misrepresentation of womenôs role in the society in general has become increasingly prominent in the thematic concerns of contemporary home video producers. Some home video producers view womenôs body as sex symbol through which their video films can record high patronage. To some critics, the misrepresentation of women in African films, especially in Nollywood and Ghallywood, should be blamed on the patriarchal structure of the society.

The portrayal of pornography has taken a new dimension in this contemporary age. The media is a veritable means through which the woman figure has been denigrated in recent times. In order to please the gaze of male viewers/readers of the mass media, producers, most especially male producers, find the portrayal of womenô sexuality in a degrading manner as a selling point of their products. (Films and Videos)

In African traditional oral performances, for instance, it is only during performance that the oral artiste has the license to discuss sex openly. Though the Yoruba people for instance frown at the open display of sex, it usually features in the performances of traditional oral artistes who have the license to say such things during their performances. According to Okediji (1991)

The male genitals are called okó, the female are $\grave{o b o}$, while the buttocks are called $i d i$. People, however, do not feel free to mention okó and òbò in public, because the genitals are not regarded as play things or common place objects. The genitals are, therefore, euphemistically called $i d i$, the name for the buttocks, but the context of the usage still indicates if reference is made to the genitals and not the buttocks. Mention of the real names of the genitals in public is regarded as 
loose talk, permitted only among the very old and careless characters.

The representations of women in popular culture as opined by Adeleye-Fayemi (2008) are a direct reflection of how they are perceived in the society. It is important to note that both the producers/controllers of technology play vital roles in the representation of women in popular arts such as home videos. This important function is carried out while entertainment is on the way. It must also be noted that entertainment provides the context within which home videos can easily be understood, experienced and enjoyed. In fact, film producers inject their messages with entertainment and it is only the thinking audience who can unravel the mysteries embedded in films. Adeleye-Fayemi (2008) opines that ñé the use of sex broadens the commercial space of producers. Through their sex stories, it is noted the male film producers utilize the inordinate amount of space they have to titillate and excite the imagination of their audiences. Apart from this, they also find legitimatisation in doing soò (emphasis ours). The use of sexual imageries in African (Ghallywood and Nollywood) video/films especially those produced by male film producers, help producers gain much popularity in the society. This reality clearly highlights the relationship that exists between films and depiction of women as sex symbols.

In a study which examines how Nigerians especially the women audience interpret the representation of their gender in Nigerian Home Videos, Adesina (2010) opines that ñthe representations of women in Nigerian films appear to be subtle images that negotiate and create ñnormalò gender identity for women as inferior subjects and as ñimmoralò people that are morally corruptò. According to him, women are mostly represented as inferior subjects when compared with their male counterparts. The most striking and revealing part of the issue is the attitude of male viewers to these films. It is believed that most men do not see anything wrong with the films, but on the contrary they see the films as didactic, as a means of stimulating women to change their ways of life.ò 
In another development, Kwenda (2007) asserts that the most over used themes in African cinematographic narrative is the portrayal of women as witches. Although the images of women as witches also exist in both Nigerian and Ghanaian home video films but whenever it is compared in relation to that of men, it is always in the lowest proportion. Concerning the images of women as mother-in-law in films, Kwenda (2007) comments that the ñmother-in-law in the video films may bewitch her daughter-inlaw by causing her barrenness so that her husband would leave herò. The way women are portrayed in Nigerian and Ghanaian home videos, therefore, calls for a serious attention in the sense that there needs to be a review of roles towards positive portrayal of women.In the world of advertisement, women are also used as sex objects in order to catch the attention of the audience to a product. The womanô body is often used as a target through which the message in the advertisement gets to the audience especially the male audience. To corroborate this, Akpabio and Oguntona (2005) assert that ñthe advertising world probably because it is mostly dominated by the men folk appears to be perpetuating the same stereotypes that have elicited the questioning of the status $q u o$ in the use of language.ò It has also been observed that women are also collaborators in this act. In a similar manner, Okunna (2012) submits that ñmen still produce an overwhelming majority of the messages in the mass mediaò. Most of the times, in advertisement, womenôs photographs are used as mere decorations in advertisements even when the advert does not have anything to do with them.

Hip hop music videos have also been used as an avenue for the flagrant display of women as sex symbols. They are displayed as dancers partially or completely showing sensitive parts of their bodies. This is achieved through the help of the camera. The camera is used to zoom in on cleavages and gyrating hips of women especially young ladies who most especially do it for monetary gain. It is in this sense that Oikelome (2013) opines that Nigerian hip hop music for instance is an avenue for the flagrant display of women as sex symbols. This is done in order to promote the status and enhance the commercial strength of the musician. He traces the misrepresentation of women in Nigerian hip $\ddot{i}$ hop 
music scene to the influences of American music culture. Generally, this is applicable to African hip $\ddot{i}$ hop music wherein these musicians want to behave or portray themselves as internationally recognized artists.

Ibie (2002) while examining the effects of colonialism on Nigeriaôs cultural production asserts that ñimperialism, on the cultural front, is about relationships, the unequal exchange of cultural products and the super-imposition of an imperial over a dependent valueò. By the virtue of colonialism and assimilation of foreign values, people in the ex-colonies, such as Nigeria, are now products of cultural hybridisation. Womenôs role in the foreign programmes as shown on local television stations gradually fires the impetus for media producers to re-create such roles in their own production. Ibie (2002) captures the situation thus:

Women columns in newspapers and magazines contain feature articled from foreign sources and which celebrate issues that range from achievement to sex. Elements of Western values are to be found even in analyses by female writers who sometimes find it fashionable to use foreign celebrities as models for their audience. Apart from that, musicals featuring known female sex symbols and other major actors on American and European television are always on air.

Even the local celebrities used in advertising their products are usually dressed provocatively in sexy wears. The pressure on musicians to market their products for public acceptance has brought about a re-conceptualisation of the goal of music in the society. Therefore, musicians are ñtorn between the need to be socially responsible and to remain financially solvent.ò Fashion and entertainment are now the two major components of contemporary songs. African proverbs also constitute one of the means through which gender stereotypes are constituted and perpetuated. In Africaôs oral tradition, proverbs are the most commonly used means through which values, norms and knowledge are transmitted from one generation to the other. To 
understand a proverb, one must have the basic knowledge of how language operates in the society. According to Hussein (2004) ñAfrican proverbs perpetuate gender legacies and ideology; they associate maleness with respect, firmness or strength, while associating femaleness with meekness, indignity inconsistency and powerlessness.ò Proverb is a means through which the notion of maleness and femaleness is developed. Usually, men use proverbs to legitimise their control over women. The following Oromo proverbs clearly illustrate womenô portraiture as sex objects:

1. A woman carrying a vagina would ask to be sexed, that the vagina is her own, but it causes trouble, the (real owner of the vagina) would be looked for.

2. One cannot be afraid of the wide vagina because it cannot sex itself.

The underlying assumption in these two proverbs is that women can at any time be used for the sexual gratification of men. Invariably it connotes that women cannot do without men. From the above, it is clear from the discussions that the way women are been portrayed in the media particularly in African films/movies have generated a lot of arguments in so many quarters without an adequate solution.

Whenever anyone picks up a video to watch either at home or in the office, one will be welcomed by a montage written as ñated PGò One may however wonder if the audiences of these films are restricted in the real sense of the matter. In this era of internet age, there are no restrictions as to whether the audiences of these films can be restricted. Every now and then, home videos laced with sexual imageries can easily be downloaded from the internet.

\section{Analysis}

In Hot Sex, a Ghallywood movie, sexual imageries take a frontline in the movie pictures. The movie is rated PG 18+. This means children below 18 years of age are not expected to watch this film. From the title, one would have suggested that the film is totally 
based on pornographic contents. This title is one that attracts the youths. Youths are usually fascinated to anything that has sexual imagery in abundance. As such, this movie in question here is based on the subject of a love that is lost between two couples. Jerry and Linda live together as husband and wife. Jerry is a working class who is so full of his job. He nearly has the time for his wife. In other words, he fails to fulfill the sexual needs of his wife. Thus, his wife finds sexual fulfillment with the driver who is always available to satisfy her sexual needs. In the other way around, Jerry also engages in an illicit affair with their house help. He uses this as a counter reaction against his wife he caught in the act. The other couple got separated on the basis that they do not understand each other. In this movie, foreplay and sexual intercourse are given vivid visual display.

Such scenes last for three to four minutes, especially the sexual encounters between the driver and Linda, Tony and Linda and the one between Jerry and their House maids. The camera is also used to zoom in on the scenes that deal with sexual intercourse. Erotic language is also used in the movie to capture the sex. Examples are ñl give a good fuckò, ñI fuck himò and ñLetôs make loveò. This type of language is capable of corrupting young minds in the society. Also, in terms of language, moaning during sexual intercourse is also given prominence in this film.

In Lagos Housewives, a Nollywood movie, we are confronted with women whose husbands travel abroad in search of greener pastures. These women are left in Nigeria to take care of their children. For this set of women to satisfy their sexual pleasure denied them by husbands who have travelled abroad, they engage in lesbianism. These house wives establish a sisterhood where they pick themselves one by one. Their slogan is ñLagos Housewives, we make it happenò. Mike approximately went to the village to pick a wife because he could not trust his properties with city girls. Nora and her partner engage in lesbianism because their husbands are not in town. Nora then advises her lesbian partner not to get pregnant again for her husband. Nora notes that Tony, her husband is her ñATM machine, bank, withdrawal slip, and Cheque bookò. Thus, after giving Tony, her husband, a son, she does not care any 
longer. She therefore advises her lesbian partner to follow suit. In this film, lesbian acts are given prominent display in such a way that the scenes last for about two to three minutes. Romantic scenes between two lesbian partners are also given prominence. Films like this give the audience, especially the youths; the idea of what it takes to be a lesbian and does not augur well when morality is concerned.

In I am a Virgin, a Nollywood movie, Johnny does not believe in pre-marital sex and therefore wants to stay a virgin till his wedding day. This is contrary to the popular belief that women are the ones who have to stay as a virgin till their wedding night. Tina who is a fiancée to Johnny never believed in this moral sanctity. She continues to pester Johnny but all to no avail. However, she is ready to continue with the relationship as long as Johnny is sponsoring her education in the university. Wilson, Johnnyôs brother takes interest in Tina. He deceived Tina by giving her false information that his brother is impotent because he had contacted a sexually transmitted disease. Wilson later takes her to a hotel where they both had fun. She later got pregnant along the way and was sent packing. Johnny later got married to another woman. The scene in which there was vivid display of sex was given prominence in the play. This is also unhealthy for the audience, especially the young minds.

In Bait of Doom a Nollywood/Ghallywoodmovie, Sophia (Mercy Johnson) was in love with Raymond because of his riches. Raymond gave a testimony in church that he won a huge contract which will fetch him several millions of naira. Sophia, a member of the church, sought out ways to connect Raymond which she actually achieved at the end of the day. She was employed as a secretary in Raymondôs company. This gives her an ample opportunity to seduce Raymond. This she did by seductively opening up her breast. Raymond eventually succumbed and he was doomed for it. Seductive wears dominate this movie. This is one of the avenues through which the audience learns fashion. In this contemporary age, we are daily confronted with all kinds of dress culture among youths which practically gives room for the display of their breast and other seductive parts of their body. 


\section{Conclusion}

There is no doubt in the fact that the producers of Nollywood/Ghallywood movies have gone a step further to portray women as sex symbols in most of their films. This is inimical to the positive projection of African women to the outside world. Though this set of films is always tagged with parental guidance, no strict guidelines have been followed in pursuance of this claim. The development of technology has also aggravated the means through which the audience can get access to these films. As such, the society is in the danger of promoting all forms of immorality. In this regard, the Nigerian Video Film Censor Board needs to take a decisive step in combating this menace.

\section{References}

Adedeji, J.A. and Hyginus, E. (1998).Nigerian theatre: Dynamics of a movement. Ibadan: Caltop Publications Limited.

Adeoti, G. (2014). Nigerian video films in Yoruba. $C B A A C$ Occasional Monograph, No. 30.

Adesina, A. (2010). Audience perception of portrayals of Women in Nigerian Home Video Films. Journal of Media and Communication Studies, 2 (9), 200-207.

Eno, A. and Titilola, O. (2011). Patriarchal universe of advertising: The Nigerian example. Journal of Social Science, 11(2), 97-100.

Fayemi-Adeleye, B. (2008). Gender, sexuality and popular culture in Nigeria.Retieved April 16, 2015, from http://quod.lib.umich.

Garritano, C. (2014). African video movies and global desires: A Ghanaian history. Ohio University Research in International Studies Africa Series No. 91.

Hussein, J. (2004). Cultural representation of women in the Oromo society. .African Study Monographs, 25 (3), 103-147. $\begin{array}{llll}\text { Retrieved } & 24 & \text { Oct. } & 2014,\end{array}$ http://www.africa.kyotou.ac.jp/kiroku.

Kwenda, G. (2007). The portrayal of witchcraft, occults and magic in popular Nigerian video films. A research report submitted to the Faculty of Arts, University of 
Witwatersrand, Johannesburg. Retrieved 18 May 2015, from http://uctscholar.uct.ac.za/.

Oikelome, A. (2013). Are real women just bad porn? Women in Nigerian Hip-Hop culture. Journal of Pan African Studies, 5(2), 83-93.

Okediji, M. (1991). The naked truth: Nude figures in Yoruba art. Journal of Black Studies, 22(1), 30-44. Retrieved 23 April 2015, from http://www.jstor.org/stable/2784495.

Okunna, C. (2012). Gender and communication in Nigeria: Is this the twenty-first century? A Monograph. Retrieved 20 May 2015, from http://portalcomunicacion.com/.

Ogazie, C.A. (2009). Home video as a weapon for change in Nigerian society. Obudu Journal of Languages, 9 (1), 210218.

Ogunbiyi, Y. (Ed.). (1981). Drama and theatre in Nigeria: A critical source book. Lagos: Pitman Press. 